\title{
STUDI PENDAHULUAN OZONASI (KATALITIK DAN NON KATALITIK) LIMBAH CAIR KARBOFURAN
}

\author{
Enjarlis $^{1,2)}$, S. Bismo ${ }^{1)}$, Slamet ${ }^{1)}$ dan Roekmijati ${ }^{1)}$
}

\begin{abstract}
Karbofuran adalah insektisida yang banyak digunakan oleh petani padi di Indonesia. Di perairan karbofuran berpotensi membentuk organoklorida dengan klor atau turunan klor. Oleh sebab itu, karbofuran digunakan sebagai objek penelitian untuk disisihkan dalam air dengan proses ozonasi. Proses ozonasi mampu menguraikan organik kompleks menjadi sederhana dan meningkatkan sifat biodegradable. Tujuan penelitian yaitu membandingkan penyisihan karbofuran dalam air dengan proses ozonasi non-katalitik dan katalitik menggunakan katalis karbon aktif. Ragam percobaan yaitu pH (2, 7, dan 9) pada suhu kamar selama 60 menit. Analisis konsentrasi karbofuran menggunakan kromatografi gas dan konsentrasi zat organik sebagai Chemical Oxigen Deman (COD) secara titrasi pada satiap10 menit selama 60 menit. Hasil percobaan memperlihatkan proses ozonasi katalitik dan non-katalitik terbaik pada kondisi basa (pH 9) dengan penyisihan karbofuran $100 \%$ dan COD turun dari 134 ppm menjadi 38 ppm untuk ozonasi katalitik, sedangkan pada ozonasi non-katalitik penyisihan karbofuran 46,4\% dan COD turun menjadi 70 ppm. Perubahan suhu dan pH selama proses baik ozonasi katalitik maupun non-katalitik tidak menunjukkan perubahan yang berarti.
\end{abstract}

Kata kunci: Karbofuran; karbon aktif; ozonasi kataliti; ozonasi-non katalitik

\section{Pendahuluan}

Pencemaran air, ikan, ASI, manusia dan tanah oleh pestisida misalnya senyawa golongan organoklorida sudah memprihatinkan seperti terjadi di daerah sentra produksi sayuran Lembang dan Pengalengan, Bandung, Jawa Barat (Subyanningsih, 1993). Senyawa golongan organoklorida akan selalu ditemukan di lingkungan terutama di perairan walaupun penggunaannya sudah dilarang. Hal ini di sebabkan senyawa organoklorida di lingkungan perairan dapat terbentuk dari hasil reaksi pestisida karbofuran dengan senyawa klor atau turunan klor. Klor atau turunannya di perairan berasal dari limbah industri yang menggunakan klor misalnya sebagai desinfektan atau pelarut yang di buang ke perairan.

Karbofuran senyawa racun terhadap ikan dan mamalia yang sampai saat ini masih digunakan oleh petani padi di Indonesia. Akibatnya, pencemaran air irigasi oleh karbofuran tidak dapat dihindari. Di samping itu penggunaan pestisida karbosulfan, benfuracarb, dan furathiocarb sebagai pembunuh hama oleh petani padi turut meningkatkan jumlah karbofuran di perairan karena karbofuran merupakan metabolit pestisida tersebut. (Hideyuki et al., 2005).

Keberadaan senyawa organoklorida di lingkungan perairan harus di kurangi salah satunya dengan cara menguraikan karbofuran yang terdapat di perairan. Proses yang berkembang saat ini dan dapat menguraikan karbofuran dalam air adalah proses reaksi karbofuran dengan $\mathrm{O}_{3}+\mathrm{UV}$ dan $\mathrm{UV}+\mathrm{H}_{2} \mathrm{O}_{2}$ (Benitez., et al, 2001) atau senyawa kompleks $\mathrm{Fe}(\mathrm{III})+\mathrm{UV}$
(Hideyuki et al., 2005) ke-tiga proses ini sering disebut proses oksidasi lanjut. Kelemahan proses ini yaitu sumber UV mempunyai life-time terbatas dan dalam skala besar lebih mahal. Oleh sebab itu, penguraian karbofuran dengan ozonasi bersamaan dengan karbon aktif sebagai katalis (ozonasi katalitik) perlu dilakukan untuk mendapatkan biaya pengolahan yang lebih murah.

Proses ozonasi mampu mengoksidasi senyawa organik kompleks menjadi sederhana dan dapat meningkatkan sifat biodegradable sehingga sifat racun senyawa organik tersebut berkurang (Langlai.,et al, 1999). Proses ozonasi zat organik merupakan reaksi oksidasi senyawa organik oleh ozon secara langsung oleh ozon dan secara tidak langsung terutama oleh radikal bebas hidroksida $\left(\mathrm{OH}^{\circ}\right)$, radikal hidroperoksida $\left(\mathrm{HO}_{2}{ }^{\circ}\right)$, ion radikal superoksida $\left(\mathrm{O}_{2}{ }^{-}\right)$dan ion radikal ozonida $\left(\mathrm{O}_{3}{ }^{-}\right)$yang terbentuk pada saat dekomposisi ozon (Chu and Ching., 2003). Dekomposisi ozon dapat dipercepat diantaranya dengan meningkatkan $\mathrm{pH}$ atau menggunakan karbon aktif sebagai katalis, selain itu penggunaan karbon aktif dapat mengurangi kebutuhan ozon (Logemann et al., 1997; Jans and Hoigne, 1998; Beltran et al., 2001; Monia et al., 2001; Song et al., 2004), sehingga penggunaan ozon bersamaan dengan karbon aktif lebih ekonomis.

Dalam penelitian ini ozonasi karbofuran bersamaan dengan karbon aktif (ozonasi katalitik) dan tanpa karbon aktif (ozonasi non-katalitik) pada pH beragam ( 2, 7, dan 9) dan suhu kamar selama 60

\footnotetext{
${ }^{1)}$ Departemen Teknik Kimia, Fakultas Teknik, Universitas Indonesia, Depok 16424

Telp. (021) 7863515 E-mail: En_jarlis@yahoo.com

${ }^{2)}$ Departemen Teknik Kimia, Fakultas Teknologi Industri, Institut Teknologi Indonesia

Jalan Raya Puspiptek - Serpong Tangerang 15311 Telp. (021) 7561092
} 
menit. Pengukuran konsentrasi karbofuran sisa, COD, $\mathrm{pH}$ dan suhu di lakukan pada setiap 10 menit pengambilan sampel selama 60 menit.

\section{Metode}

Karbofuran $\left(\mathrm{C}_{12} \mathrm{H}_{15} \mathrm{NO}_{3}\right)$ diperoleh dari nama dagang Furadan $3 \mathrm{G}$ mengandung 3\% karbofuran. Ozon $1,2672.10^{3}$ ppm dengan laju alir 0,0845 L.menit $^{-1}$ di peroleh dari ozon prosesor RS 09805-0,25 gr buatan RESUN. Air bebas mineral untuk pembuatan larutan diperoleh dari alat Aquatron Auto Still Yamato Tipe W182.

Percobaan ozonasi dilakukan dalam reaktor 1 berisi 20 L larutan karbofuran dengan konsentrasi awal 12 ppm dan $\mathrm{pH}$ 2, atau 7, dan atau 9 serta karbon aktif berbentuk unggun (Gambar 1). Cairan limbah karbofuran dari reaktor 1 di alirkan melewati karbon aktif yang sebelumnya sudah dikontakan dengan gas ozon. Larutan dari reaktor 1 di alirkan ke-reaktor 2 dan kembali dipompakan ke-reaktor 1. Pengambilan sampel dilakukan setiap 10 menit selama 60 menit di reaktor 1 . Analisis konsentrasi karbofuran sisa menggunakan GC tipe 4C, Colum silicone ov-17 panjang 3 meter, detector ECD (Electron Capture Detector) buatan Shimadzu, pelarut $\mathrm{N}$-heksan dan gas pembawa $\mathrm{N}_{2}$ dan analisis COD ditentukan secara titrasi.

\section{Hasil dan Pembahasan}

\section{Pengaruh waktu}

Hubungan konsentrasi karbofuran selama ozonasi katalitik dan non katalitik pada $\mathrm{pH}$ 2, 7, dan 9 dapat dilihat pada Gambar 2. Dari Gambar tersebut terlihat semakin lama proses ozonasi penyisihan karbofuran semakin baik, hal ini disebabkan semakin lama proses ozonasi jumlah ozon yang terlarut dan dikonsumsi untuk mengoksidasi karbofuran secara langsung, terdekomposisi menjadi $\mathrm{OH}$ radikal dan radikal oksigen semakin banyak. Akibatnya penyisihan karbofuran semakin besar pula.

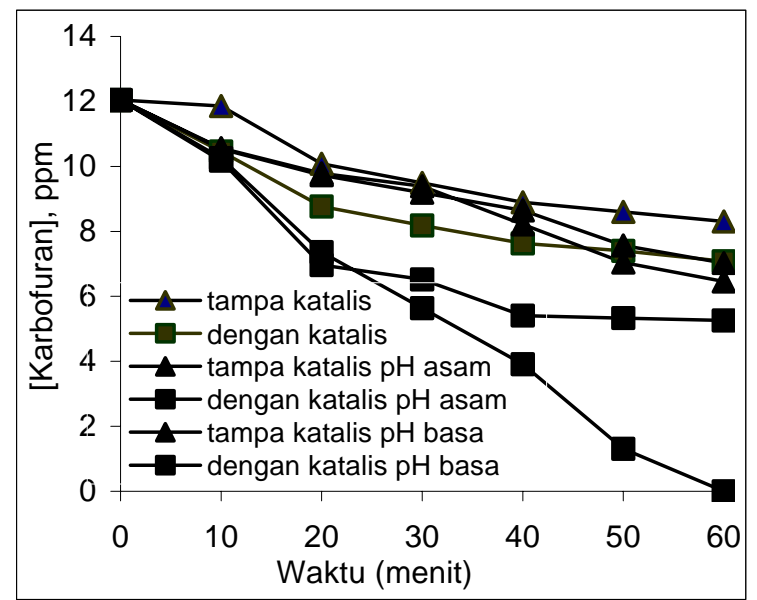

Gambar 2. Pengaruh waktu proses ozonasi katalitik dan non-katalitik terhadap konsentrasi karbofuran pada berbagai $\mathrm{pH}$

\section{Pengaruh pH}

Pengaruh $\mathrm{pH}$ terhadap penyisihan karbofuran secara ozonasi non-katalitik dapat di lihat pada Gambar 3 dan secara non-katalitik pada Gambar 4. Kedua gambar ini memperlihatkan penyisihan karbofuran terbaik terjadi pada kondisi basa (pH 9) kemudian diikuti pada kondisi asam ( $\mathrm{pH} 2$ ) dan netral (pH 7).

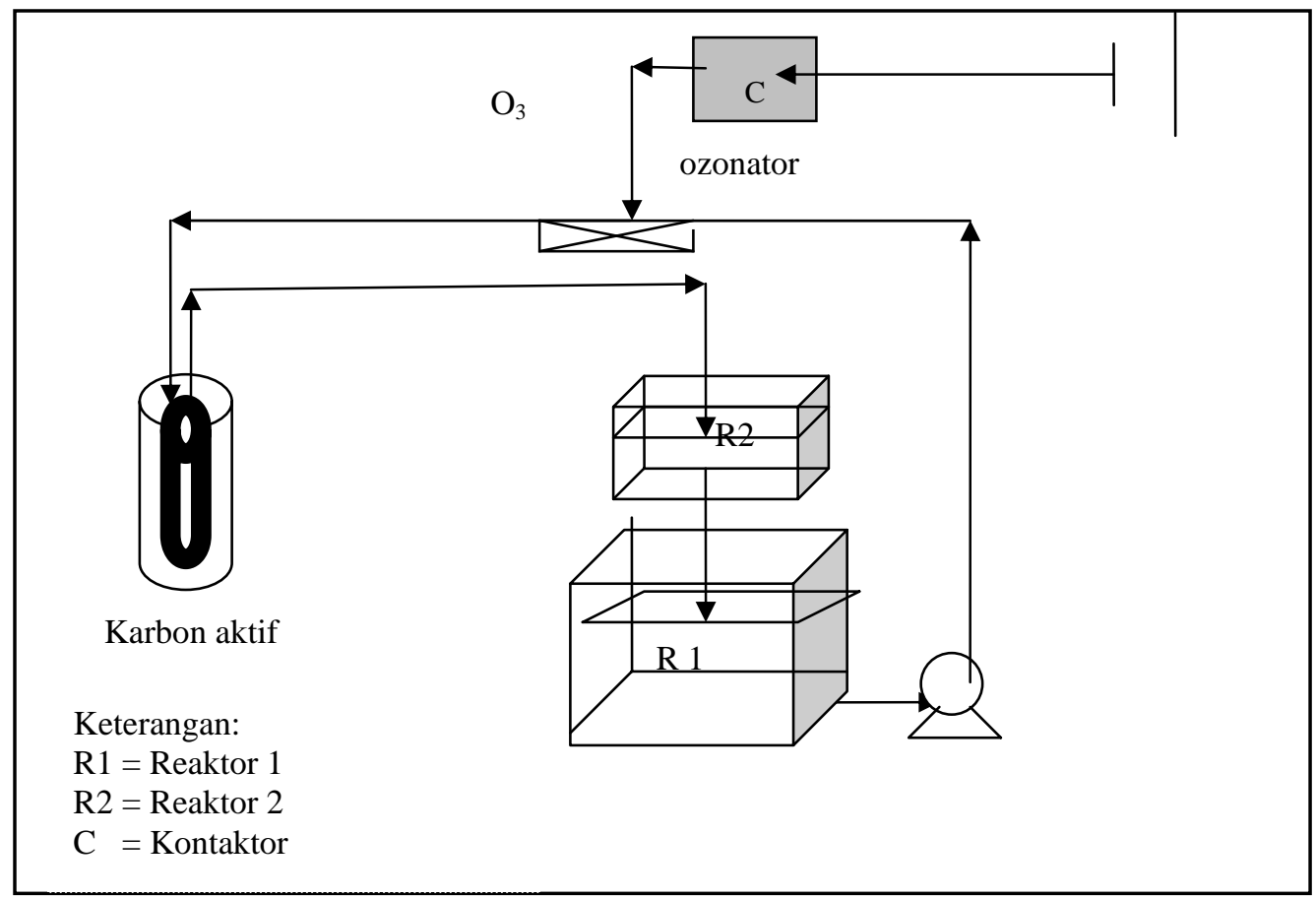

Gambar 1. Skema peralatan proses Ozonasi katalitik dan non-katalitik 


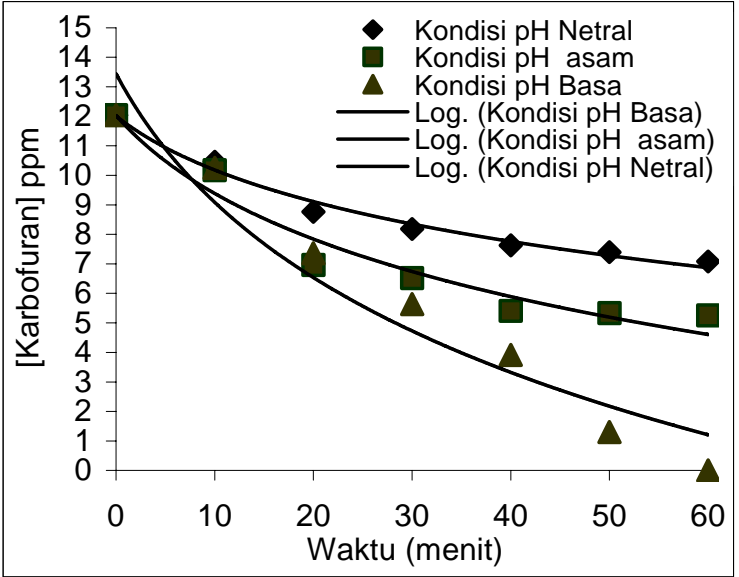

Gambar 3. Pengaruh $\mathrm{pH}$ terhadap konsentrasi karbofuran sisa selama ozonasi katalitik

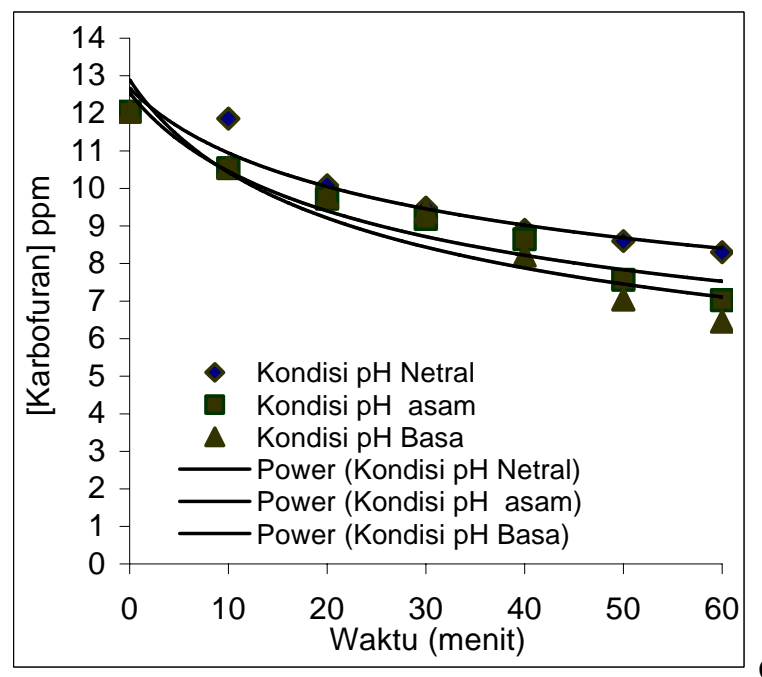

ambar 4. Pengaruh pH terhadap konsentrasi karbofuran sisa selama ozonasi non- katalitik

Pada kondisi basa (pH 9) penyisihan karbofuran secara ozonasi non-katalitik dominan terjadi karena reaksi ozonasi secara tidak langsung oleh $\mathrm{OH}^{*}$ (Logemeann., et al., 1997) dan reaksi hidrolisis melalui subtitusi nukleofilik ion $\mathrm{OH}^{-}$(Roberts et al., 1999) terhadap karbofuran. Sedangkan, penyisihan karbofuran secara ozonasi katalitik pada $\mathrm{pH}$ yang sama disebabkan terjadi beberapa reaksi karbofuran secara ozonasi tidak langsung oleh $\mathrm{OH}^{\mathbf{0}}$, oksidasi oleh radikal oksigen di permukaan katalis (Chu and Ching., 2003) dan hidrolisis secara nukleofilik oleh ion OH. (Robers et al., 1999). Akibatnya penyisihan karbofuran secara ozonasi katalitik pada $\mathrm{pH}$ yang sama lebih besar bila dibandingkan dengan ozonasi karbofuran secara nonkatalitik (Gambar 5).

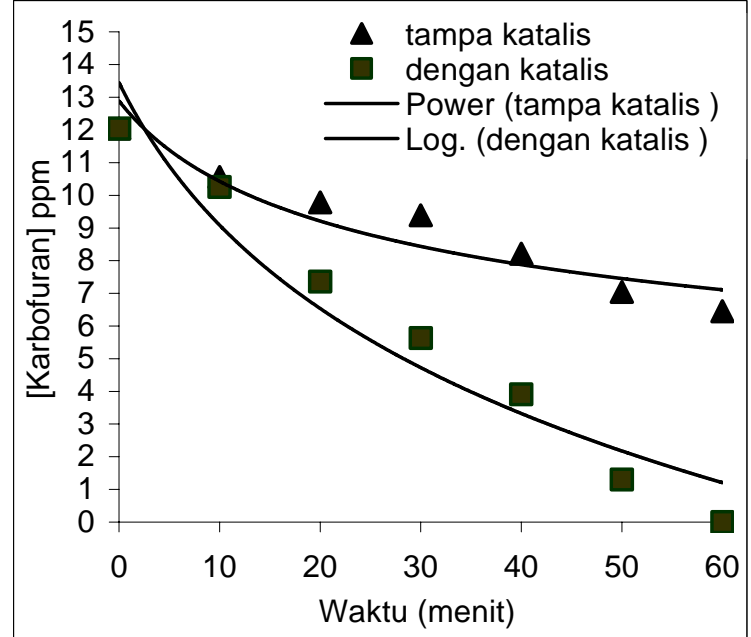

Gambar 5. Pengaruh proses ozonasi katalitik dan non-katalitik terhadap penyisihan karbofuran pada pH 9

Dekomposisi ozon dapat diawali oleh ion $\mathrm{OH}^{-}$ (Langlai et al.1991). Pada kondisi basa jumlah ion $\mathrm{OH}^{-}$yang mengawali dekomposisi ozon menjadi $\mathrm{OH}^{\circ}$ lebih besar dibandingkan $\mathrm{pH} 2$ dan 7, akibatnya jumlah $\mathrm{OH}^{\mathbf{0}}$ yang terbentuk juga lebih banyak dan reaksi ozonasi secara tidak langsung semakin besar pula pada $\mathrm{pH}$ 9. $\mathrm{OH}^{0}$ dapat mengoksidasi sebagian besar senyawa organik dengan cepat, karena mempunyai potensial oksidasi (2,8 vol) lebih besar dari ozon (2,07 vol) dan kurang selektif.

Peranan reaksi hidrolisis karbofuran dilaporkan oleh Roberts et al., (1999) bahwa pada kondisi basa (pH 9 dan $25^{\circ} \mathrm{C}$ ) half-life reaksi hidrolisis 0,54 hari, kondisi netral half-life 27,7 hari dan dikondisi asam lemah karbofuran sangat stabil. Jadi pada $\mathrm{pH}$ basa hidrolisis cukup berperan dalam menyisihkan karbofuran dalam air. Senyawa hasil hidrolisis karbofuran yang dominan dilaporkan oleh Yu et al.(1974), Seiber et al (1978), Brahma prakash et al. (1987), Talebi dan Walker (1993) dalam Robers et al. (1999) adalah karbofuran fenol dengan half-life 67 menit. Reaksi hidrolisis karbofuran yang terjadi seperti pada persamaan 1.

Pada kondisi asam (pH 2) penyisihan karbofuran secara ozonasi non-katalitik dominan yang terjadi ozonasi secara langsung oleh ozon, sedangkan ozonasi secara tidak langsung diabaikan karena pembentukan $\mathrm{OH}^{\mathbf{0}}$ sangat kecil (Beltran et al., 2001). Akibatnya, penyisihan karbofuran pada kondisi asam lebih lambat dibandingkan dengan kondisi basa $(\mathrm{pH} 9)$. Penyisihan karbofuran secara ozonasi katalitik pada $\mathrm{pH} 2$ disebabkan oleh reaksi ozonasi secara langsung oleh ozon dan radikal oksigen di permukaan katalis. Sehingga dari Gambar 6 terlihat penyisihan karbofuran pada $\mathrm{pH} 2$ secara ozonasi katalitik lebih besar dibandingkan ozonasi non-katalitik. 


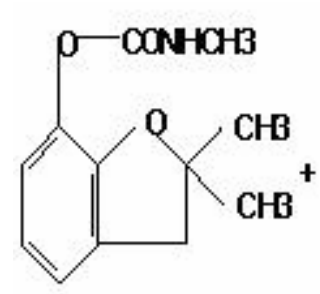

Karbofuran<smiles>CC1(C)Cc2ccc(O)c(O)c2O1</smiles>

Karburanferol

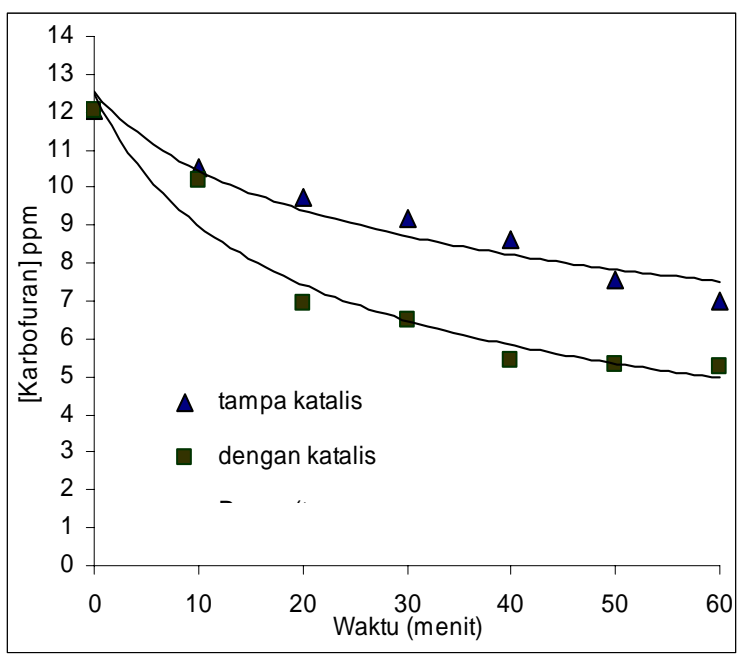

Gambar 6. Pengaruh proses ozonasi katalitik dan nonkatalitik terhadap penyisihan karbofuran selama Pada pH 2.

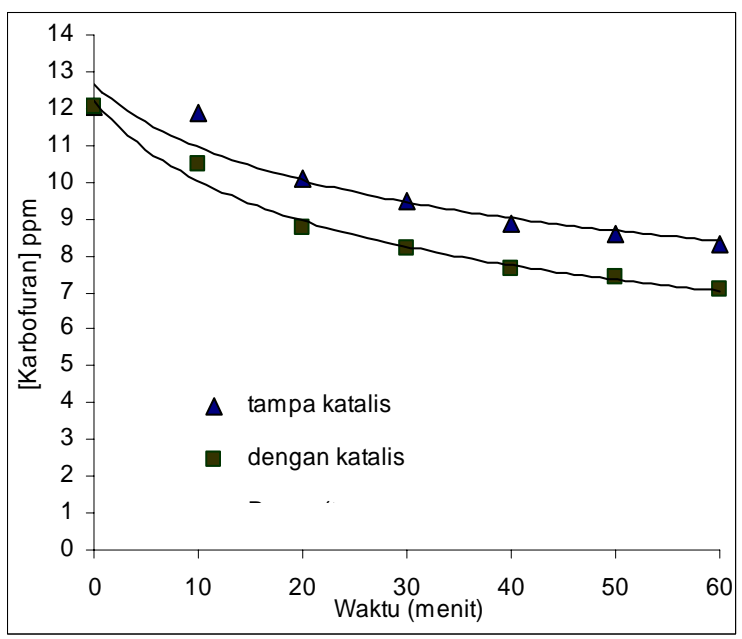

Gambar 7. Pengaruh proses ozonasi katalitik dan nonkatalitik terhadap penyisihan karbofuran pada $\mathrm{pH} 7$

Pada kondisi netral ( $\mathrm{pH} 7$ ) penyisihan karbofuran paling rendah dibanding dengan kondisi lain (pH 2 dan 9) baik secara ozonasi katalitik maupun non-katalitik. Hal ini disebabkan pada pH tersebut ozonasi karbofuran secara langsung oleh ozon dan secara tidak langsung oleh $\mathrm{OH}^{\mathbf{0}}$ berlangsung lebih singkat dibandingkan pada

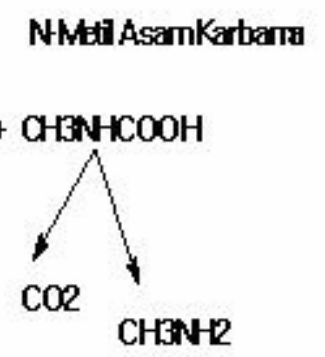

$\mathrm{pH}$ 2. Dengan demikian berkurangnya karbofuran lebih kecil dibandingkan $\mathrm{pH} 2$ dan $\mathrm{pH} 9$.

Gambar 7 memperlihatkan penyisihan karbofuran pada pH 7 secara ozonasi katalitik lebih besar dibandingkan dengan ozonasi non-katalitik, hal ini disebabkan pada ozonasi katalitik terjadi reaksi karbofuran dengan ozon dan dengan radikal $\mathrm{OH}$ lebih besar dibandingkan ozonasi non-katalitik.

Dari ketiga pH (2, 7, dan 9) percobaan yang digunakan untuk ozonasi karbofuran baik secara katalitik maupun non-katalitik (Gambar 5, 6 dan 7) memperlihatkan penyisihan karbofuran secara katalitik lebih cepat dibandingkan secara ozonasi non-katalitik. Hal ini disebabkan katalis karbon aktif dalam proses ozonasi dapat mempercepat dekomposisi ozon menjadi $\mathrm{OH}^{\mathbf{0}}$ dan radikal oksigen (Logemann et al., 1997; Jans and Hoigne, 1998; Beltran et al., 2001; Monia et al., 2001; Song et al., 2004).

Permukaan karbon aktif disamping berpori juga mengandung gugus asam dan basa (Laszlo et al., 2001). Gugus asam pada karbon aktif menyebabkan reaktifitas ozon terhadap karbon aktif berkurang dan ozon dalam pori lebih banyak terdekomposisi menjadi radikal oksigen seperti $\mathrm{O}^{-}, \mathrm{O}_{2}^{-}$, dan $\mathrm{O}_{3}^{-}$ (Utrilla et al. 2003). Gugus basa pada karbon aktif akan mempercepat dekomposisi ozon menjadi $\mathrm{OH}^{\mathbf{0}}$ melalui reaksi (2) dan (3) [Polo et al., 2005]. Ion $\mathrm{OH}^{-}$ dan senyawa $\mathrm{H}_{2} \mathrm{O}_{2}$ yang dihasilkan merupakan senyawa yang dapat mengawali dekomposisi ozon menjadi $\mathrm{OH}^{\mathbf{0}}$. Reaksi pembentukan $\mathrm{OH}^{-}$dan $\mathrm{H}_{2} \mathrm{O}_{2}$ sebagai berikut:

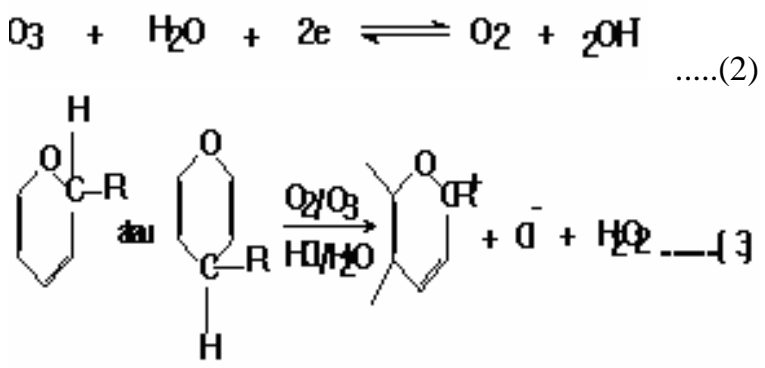

Perkiraan reaksi ozonasi secara langsung oleh ozon terhadap senyawa hasil hidrolisis karbofuran yaitu karbofuran fenol dan N-metil asam karbamat di sajikan pada Gambar 9 dan Gambar 11. 


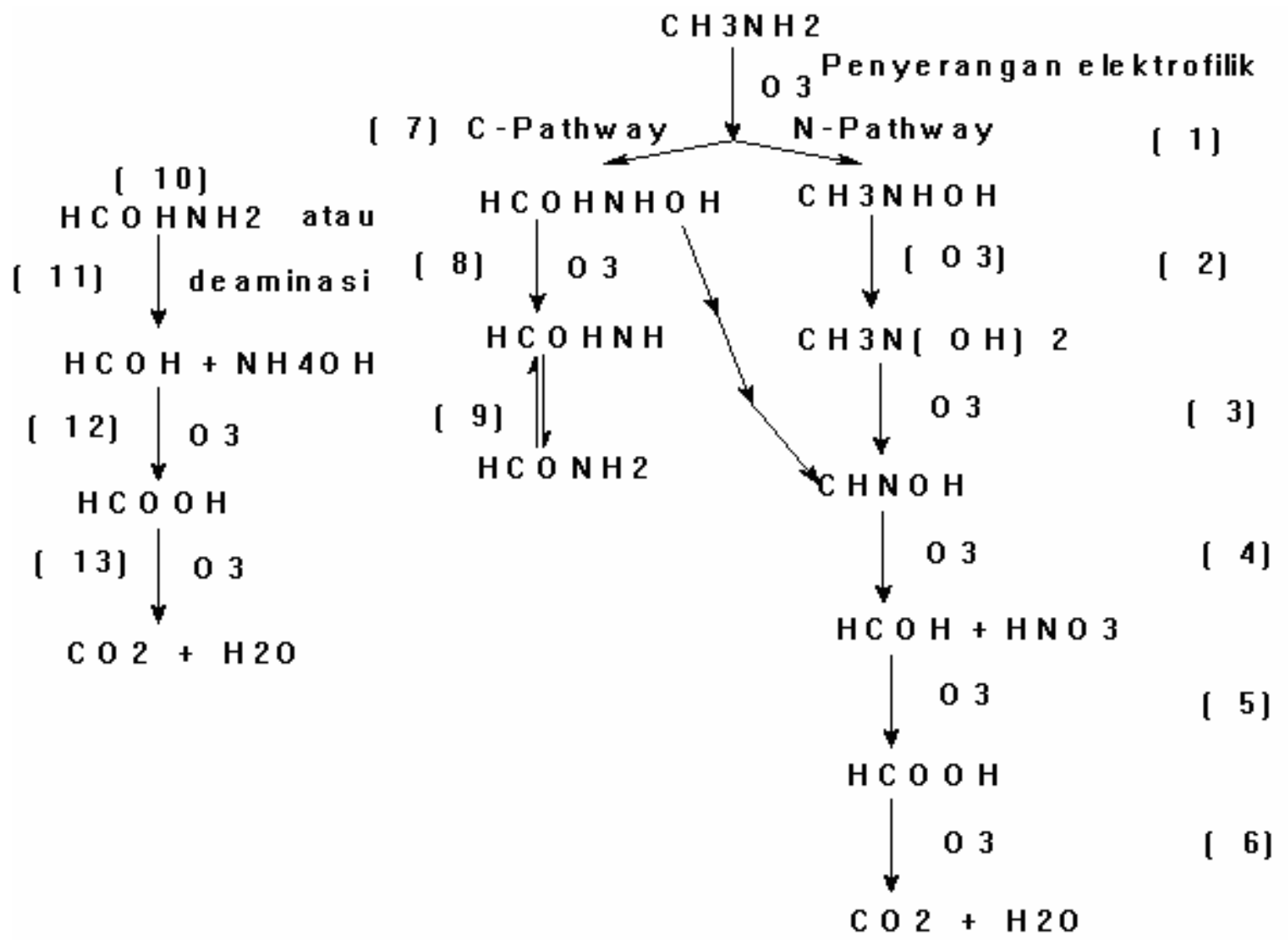

Gambar 9. Reaksi ozonasi metil amin (Langlai, et al., 1999)

Reaksi tersebut berlangsung cepat dengan ozon, karena senyawa-senyawa tersebut mempunyai ikatan yang sangat polar seperti $\mathrm{C}-\mathrm{N}, \mathrm{N}-\mathrm{H}, \mathrm{C}=\mathrm{O}$ dengan nilai momen ikatan masing-masing 0,22 , 1,31, dan 2,3. Penyerangan karbofuran fenol oleh ozon terjadi secara elektrofil pada gugus aromatik di posisi orto dan para.

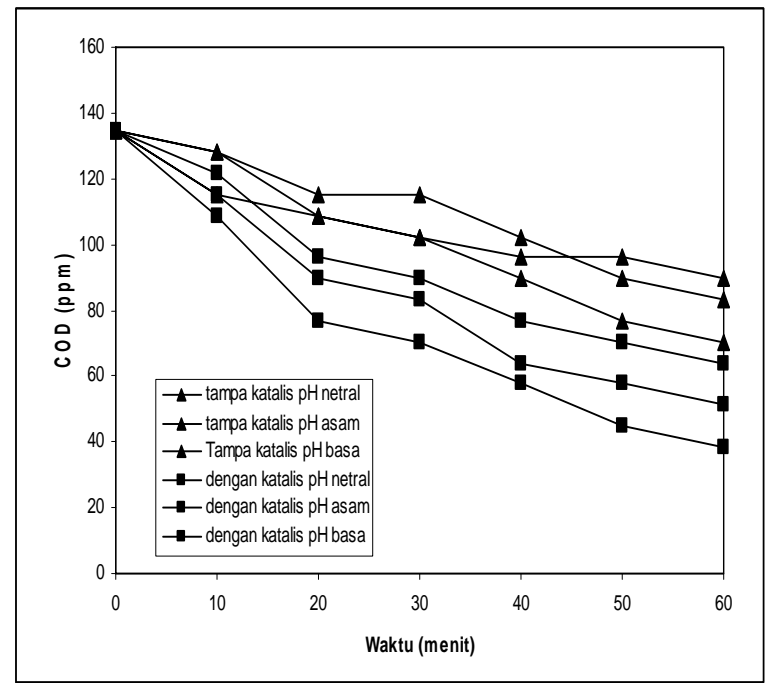

Gambar 8. Perubahan COD limbah karbofuran selama ozonasi katalitik dan non-katalitik pada berbagai $\mathrm{pH}$
Perubahan COD limbah karbofuran selama ozonasi katalitik dan non-katalitik pada berbagai $\mathrm{pH}$ dapat di lihat dari Gambar 8.

Gambar tersebut memperlihatkan tren yang sama dengan penyisihan karbofuran baik secara ozonasi katalitik maupun non-katalitik. Pengurangan COD yang terbaik terjadi pada $\mathrm{pH}$ basa $(\mathrm{pH} 9)$ kemudian baru di ikuti $\mathrm{pH}$ asam $(\mathrm{pH} 2)$ dan netral (pH 7). Pengurangan COD disebabkan karbofuran teroksidasi dan terhidrolisis menjadi senyawa sederhana, kemudian senyawa sederhana akan dioksidasi oleh ozon menjadi karbon dioksida dan air. Dari Gambar tersebut terlihat juga pengurangan karbofuran tidak sebanding dengan pengurangan COD, hal ini disebabkan karbofuran yang digunakan mempunyai kemurnian yang rendah sehingga COD awal 134 ppm sangat besar dibandingkan konsentrasi karbofuran awal (12 ppm) dan begitu juga setelah proses ozonasi baik secara katalitik maupun nonkatalitik.

Prosentase penyisihan karbofuran selama ozonasi katalitik dan non-katalitik diberbagai $\mathrm{pH}$ dapat di lihat pada Gambar 10. Gambar tersebut memperlihatkan prosentase penyisihan karbofuran mengikuti tren penyisihan karbofuran. Pada ozonasi katalitik penyisihan terbaik terjadi pada kondisi basa $(\mathrm{pH} 9)$ sebesar 100\%, kondisi asam ( $\mathrm{pH} 2)$ sebesar $52,22 \%$ dan pada kondisi netral (pH 7) sebesar 35,62\%. Pada ozonasi non-katalitik penyisihan 


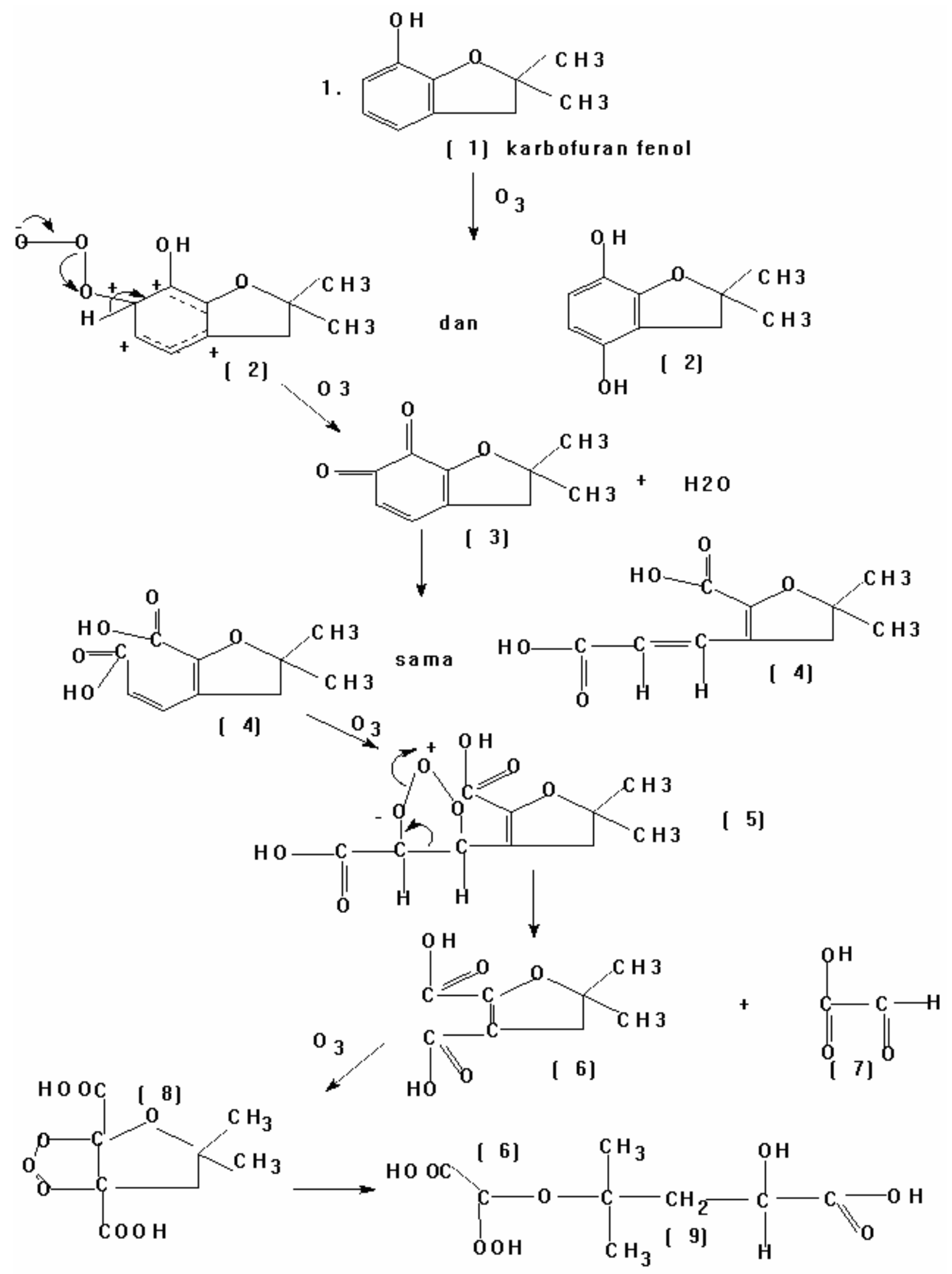

Gambar 11.. Reaksi ozonasi Kabofuran Fenol (Langlai, et al.,1999) 
karbofuran terbaik terjadi pada kondisi basa ( $\mathrm{pH} 9$ ) sebesar 46,4\%, kemudian diikuti pada kondisi asam $(\mathrm{pH}$ 2) sebesar 41,66\% dan kondisi netral $(\mathrm{pH}$ 7) sebesar $31.06 \%$.

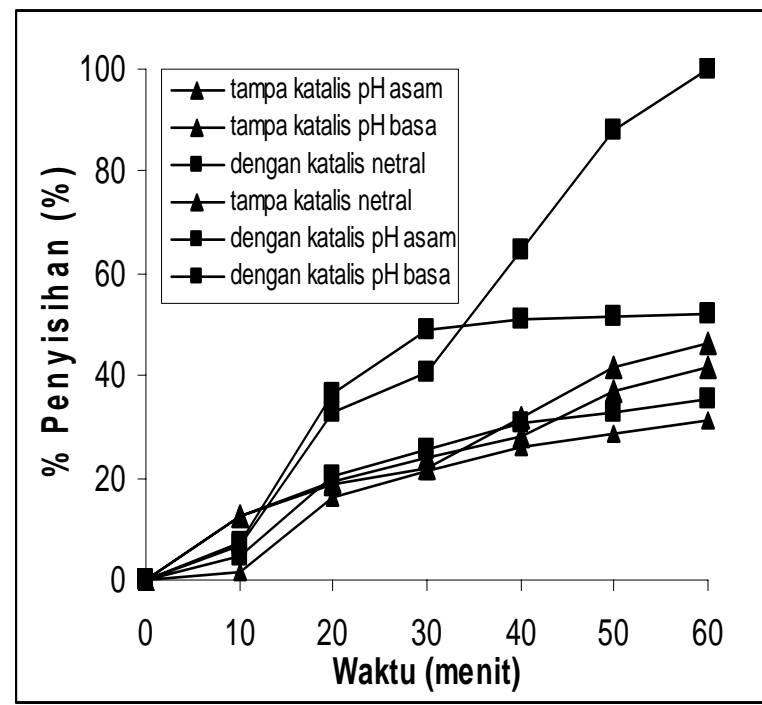

Gambar 10.

Prosentase penyisihan karbofuran selama ozonasi

katalitik dan non-katalitik pada berbagai $\mathrm{pH}$

Selama proses ozonasi katalitik dan non-katalitik di- berbagai kondisi (asam, netral dan basa) dan suhu kamar tidak menunjukan penurunan atau kenaikan $\mathrm{pH}$ dan suhu yang berarti. Hal ini disebabkan jumlah karbofuran sangat kecil (12 ppm) dalam volume yang besar (20 Liter), sehingga senyawa asam-asam yang terbentuk tidak mempengaruhi $\mathrm{pH}$ larutan dan suhu yang berarti. Reaksi ozonasi berlangsung pada suhu kamar sehingga bila terjadi kenaikan suhu tidak mempengaruhi suhu larutan.

\section{Kesimpulan}

Studi pendahuluan ozonasi (katalitik dan nonkatalitik) limbah cair karbofuran, dapat disimpulkan bahwa ozonasi katalitik dengan katalis karbon aktif sangat efektif dalam penyisihan karbofuran di bandingkan dengan ozonasi non-katalitik.

Pengurangan konsentrasi karbofuran selama proses ozonasi diikuti dengan pengurangan COD dan peningkatan prosentase penyisihan karbofuran. Kondisi larutan karbofuran untuk disisihkan dengan proses ozonasi katalitik dan non-katalitik terbaik pada kondisi basa ( $\mathrm{pH}$ 9), kemudian diikuti pada kondisi asam ( $\mathrm{pH} 2)$ dan kondisi netral ( $\mathrm{pH} \mathrm{7).} \mathrm{Selama} \mathrm{ozonasi} \mathrm{karbofuran}$ baik secara ozonasi katalitik maupun non-katalitik tidak memberikan perubahan $\mathrm{pH}$ dan suhu yang berarti.

\section{Daftar Pustaka}

Beltran, F. J., Rivas, F. J., Alvarez, P., And Montero, R., (2001)., "Kinetic of Ozone Decomposition Catalyzed by Activated Carbon in Water", Proceedings of The 15 th World Congress, London, Vol. 1, pp. 28 -36 .

Chen-Hung Ni, Chen, J. N., dan Tsai Y.C., (2002)., "Heterogen Catalytic Ozonation of 2-Dichlorophenol Using Zeolite as a Catalys", Ozone Sci. and Eng. Environ. Processes and Tech. Appl. Proceeding of the International Conference,Hongkong, pp. 201 209.

Chu, W., and Ching, M. H., (2003), ”Modeling the ozonation of 2,4-dichlorophoxyacetic acid through a kinetic approach”, Water Res, 37, pp. 39-46.

Guiza, M., Ouederni, A., Ratel, A., (2004), "Decomposition of Dissolved Ozone in the Presence of Activated Carbon: An Experimental Study Ozone” Ozone Sci. and Eng., 26 (2004), pp 299 - 307.

Howard, P. H., Robert, S., Boethling, Wiliam F. J., William, M., Meylan, Michalenko, E,M., (1997), Environmental Degradation Rates, Editor Heather Taub Printup. Lewis Publishes.

Katsumata, H., Matsuba, K., Kaneco, S., Suzuki, T., Ohta, K., Yobiko, Y., (2005), "Degradasi of Carbofuran in aqueous solution by $\mathrm{Fe}(\mathrm{III})$ aquacomplexes a effective photocatalysts”. Journal of Photochemistry and Photobiology A : Chemistry 170.,pp. 239-245.

Laslzlo, K.,.,.Jospovits,K., and Tombacz, E., (2001). "Analysis of Active Sites on SyntheticCarbon Surfaces by Various Methods” Anal. Sci. Suppl., 17,pp.i1741-i1744.

Logemann, F.P., and Anee, J.H.J., (1997). "Water Treatment With A Fixed Bed Catalytic Ozonation Process”.,Water. Sci. Tech., 35, ,pp. 353-360.

Langlais Bruno, David . Reckhow, Deborah.. Brink. (1991)., "Ozone in Water Treatment Application Engineering”, Cooperative Research Report.Florida. Lewis Publishing.

Ma, J., dan Minghao, S., (2002),” Removal of Organic Micropollutants From Water by Activated Carbon Catalysed" Ozone Sci. and Eng. Environ Process and Tech Appl., .Proceeding of the International Conference,Hongkong, hal 176 - 182.

Polo Sanchez, M. , Ramos Leyva- Ramos, RiveraUtrilla., (2005)., "Kinetics of 1,3,6-naphthalene trisulphonic acid Ozonation in presence of activated carbon”, Carbon., 43, pp. 962-969.

Sudibyaningsih, T., (1993), "Pestisida Dalam Bahan Pangan anak Balita Keluarga Petani sayur di daerah Lembang dan Pengalengan” Thesis. Universitas Pajajaran, Bandung.

Wang, Q., and Lemley, A.T., (2003)., “Oxidative degradation and detoxification of aqueous carbofuran by membrane anodic Fenton treatment”, Journal of Hazardous Materials, pp. 241-255. 
Ying, H. J., Morita, T., Magara, Y., and Aizawa, T., (2000)., "Evaluation Of Reactivity Of Pesticides with Ozone in Water Using the Energies of Frontier
Molecular Orbitals”, Waters Res., 34, 8, pp. 2215 2222. 